\title{
DOSADAŠNJE I POTENCIJALNE DJELATNOSTI U VELEBITSKOM PRIMORJU I PODGORJU
}

\author{
Joso Brajković \\ Hrvatska gospodarska komora \\ Županijska komora Otočac \\ Kralja Zvonimira 16 \\ HR 53220 Otočac \\ jbrajkovic@hgk.hr
}

\author{
UDK: 338(497.5 Velebit) \\ 658.3:332.14](497.5 Velebit) \\ Izvorni znanstveni članak \\ Ur.: 2017-01-30
}

\begin{abstract}
Gospodarska i demografska slika Velebitskog primorja i podgorja nije dobra zbog sljedećih uzroka: neatraktivnost reljefnog prostora s gospodarskog stanovišta, visok stupanj zaštite okoliša što je poduzetniku dodatan trošak, nepovoljni uvjeti financiranja poduzetništva ali i visok stupanj centralizacije države. Temeljni uzrok ovakvog ukupnog gospodarskog stanja je mali broj i struktura stanovništva, odnosno nedovoljan radno aktivni kontingent stanovništva. Postojeća starosna, dobna i obrazovna struktura stanovništva je nepovoljna i nedovoljna za razvoj gospodarstva zbog demografskih promjena u prošlosti, spore industrijalizacije, urbanizacije i deagrarizacije što je rezultiralo emigracijom i depopulacijom. Nekada dominantne djelatnosti poljoprivreda, ribarstvo i stočarstvo, zamijenili su turizam, trgovina i ugostiteljstvo, manje proizvodnja. Za gospodarski razvoj ovoga prostora važni su Park prirode Velebit i nacionalni parkovi Sjeverni Velebit i Paklenica koji kao prirodni resursi mogu utjecati na razvoj ekoproizvodnje, ekoturizma i održivi razvoj.
\end{abstract}

Ključne riječi: Velebitsko primorje i podgorje, radno aktivno stanovništvo, decentralizacija, prirodni i ljudski potencijal, gospodarski razvoj

\section{Uvod}

U radu su analizirane dosadašnje, i razvoj budućih gospodarskih djelatnosti na području Velebitskog primorja i podgorja. Korištenjem povijesne, komparativne, deskripcijske, induktivne i deduktivne metode, statističke metode te metode kompilacije, analize i sinteze, analiziran je ovaj prostor. U obzir je uzeta prostorna i zemljopisna komponenta, prirodni resursi i struktura stanovništva kao najvažniji resurs gospodarskog razvoja, a on ne ovisi samo o kapitalu i tehnologiji, već i o raspoloživom kontingentu radno 


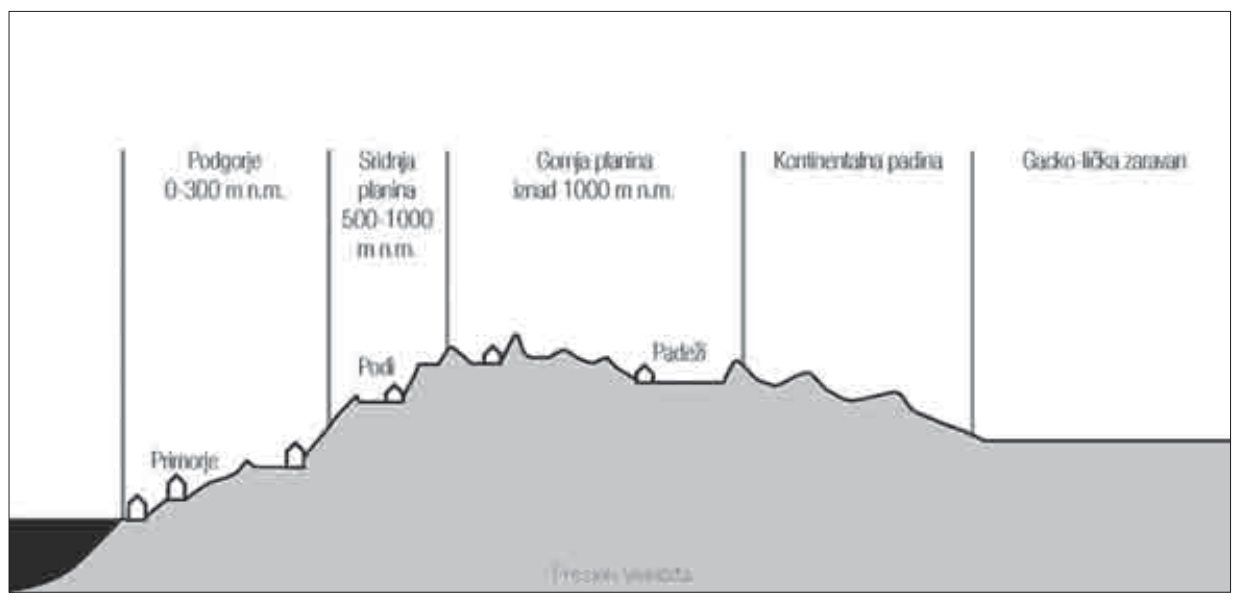

S1. 1. Presjek Velebita, Velebit Arhitektonski, 25. preuzeto iz Hrvatske revije, 1, 2014.

aktivnog stanovništva. To je veliki problem za gospodarski razvoj jer je ovo područje izloženo stalnoj depopulaciji i iseljavanju stanovništva, a posljedica toga je smanjenje radno aktivnog kontingenta stanovništva.

Objašnjene su gospodarske djelatnosti koje su nekada postojale, te navedeni razlozi njihova nestanka i ograničenja koja postoje za razvoj gospodarstva Velebitskog primorja i podgorja. Analizom prostornih planova jedinica lokalne uprave i samouprave, u kojime se nalazi Velebitsko primorje i podgorje utvrđene su gospodarske djelatnosti koje se planiraju razvijati, te su predložene mjere koje bi trebalo poduzeti s razine države kako bi se povećale financijske i kadrovske mogućnosti jedinica lokalne samouprave za oporavak gospodarstva odnosno kako bi državne institucije više pažnje posvetile gospodarskom i demografskom oporavku Velebitskog primorja i podgorja.

\section{Prostorno i zemljopisno obilježje Velebitskog primorja i podgorja}

Velebitskim primorjem i podgorjem smatra se područje na sjeveru ograničeno zaljevom između Bunice i Batine (Grad Senj) do kote 296,1 m n.v., a na jugu auto-cestom A-1 (Zagreb-Split) i ulaskom u Novsko ždrilo. U radu je korištenjem karte iz internet portala "Geoportal" izmjerena površina Velebitskog primorja i podgorja do visine od $300 \mathrm{~m} \mathrm{n.v.} \mathrm{(površine} \mathrm{183,56} \mathrm{km²),}$ 500 m n.v. (površine 275,64 km²) i 700 m n.v. (površine $395,82 \mathrm{~km}^{2}$ ), što je važno zbog planiranja izgradnje stambenih naselja i razvoja gospodarstva. 

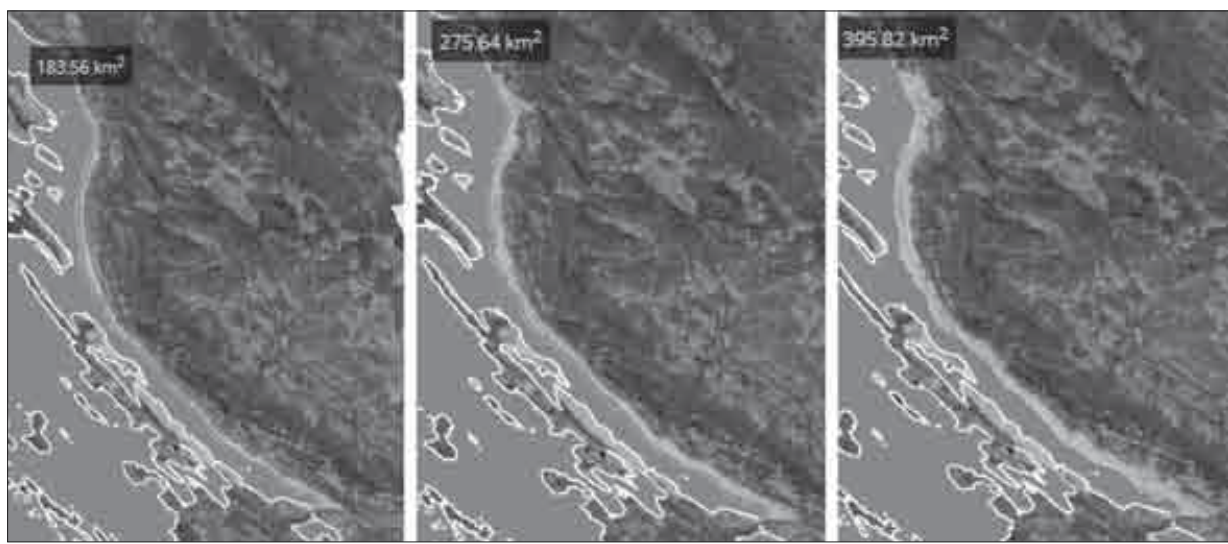

Sl. 2. Velebitsko primorje i podgorje, Geoportal, mjerilo 1:1 000 000, obrada: autor

Za ovaj prostor i njegova obilježja H. Knifić Shaps, $(2017,1)$ kaže: "Podgorje se u geografskom smislu (od Svetog Jurja do Starigrada Paklenice $i$ poprečno do 700 m n.v.) ne poklapa s Podgorjem u graditeljskom smislu".

Jedinice lokalne samouprave koje čine Velebitsko primorje i podgorja do visine od 700 m n.v. jesu: Grad Senj - 18 naselja (od 27), Općina Karlobag - 13 naselja (od 14), Općina Starigrad - 3 naselja (od 3), i Općina Jesenice - 1 naselje (od 2), što se vidi u Tablici 1.

Tablica 1. Naselja i broj stanovnika Velebitskog primorja i podgorja

\begin{tabular}{|l|l|c|c|c|c|}
\hline R.br. & \multicolumn{1}{|c|}{ Naselja } & Br. stan. 1981. & Br. stan. 1991. & Br. stan. 2001. & Br.stan. 2011. \\
\hline & Grad Senj & & & & \\
\hline 1. & Bunica* & - & - & - & 85 \\
\hline 2. & Jablanac & 219 & 158 & 118 & 83 \\
\hline 3. & Klada & 44 & 49 & 33 & 39 \\
\hline 4. & Lukovo & 90 & 57 & 36 & 36 \\
\hline 5. & Pijavica* & - & - & - & 262 \\
\hline 6. & Prizna & 172 & 79 & 56 & 45 \\
\hline 7. & Senj & 5.536 & 5.998 & 5.491 & 4810 \\
\hline 8. & Senjska Draga & 128 & 118 & 100 & 85 \\
\hline 9. & Starigrad & 54 & 29 & 11 & 15 \\
\hline 10. & Stinica & 229 & 145 & 105 & 73 \\
\hline 11. & Stolac & 177 & 87 & 55 & 41 \\
\hline
\end{tabular}




\begin{tabular}{|c|c|c|c|c|c|}
\hline 12. & Sveta Jelena* & - & - & - & 16 \\
\hline 13. & Sveti Juraj & 687 & 691 & 692 & 599 \\
\hline 14. & Velike Brisnice & 4 & 1 & 1 & 0 \\
\hline 15. & Vrataruša** & 135 & 180 & 262 & 11 \\
\hline 16. & Francikovac** & nema podataka & nema podataka & nema podataka & nema podataka \\
\hline 17. & Majorija** & nema podataka & nema podataka & nema podataka & nema podataka \\
\hline \multirow[t]{2}{*}{18.} & Volarice** & 224 & 194 & 112 & 86 \\
\hline & Općina Karlobag & & & & \\
\hline 19. & Barić Draga & 141 & 85 & 124 & 125 \\
\hline 20. & Cesarica & 143 & 115 & 144 & 123 \\
\hline 21. & Karlobag & 478 & 467 & 510 & 468 \\
\hline 22. & Ledenik Cesarički & 57 & 48 & 27 & 20 \\
\hline 23. & Lukovo Šugarje & 147 & 136 & 79 & 68 \\
\hline 24. & Staništa & 4 & 48 & 10 & 6 \\
\hline 25. & Sušanj Cesarički & 26 & 28 & 13 & 12 \\
\hline 26. & Vidovac Cesarički & 79 & 32 & 63 & 56 \\
\hline 27. & Crni Dabar** & 0 & 0 & 0 & 0 \\
\hline 28. & Došen Dabar ** & 0 & 0 & 0 & 0 \\
\hline 29. & Konjsko ** & 12 & 10 & 7 & 0 \\
\hline 30. & Kućišta Cesarička** & 29 & 22 & 12 & 12 \\
\hline \multirow[t]{2}{*}{31.} & Ravni Dabar** & 0 & 0 & 0 & 0 \\
\hline & Općina Starigrad & & & & \\
\hline 32. & Starigrad Paklenica & 1135 & 1159 & 1100 & 1140 \\
\hline 33. & Seline & 459 & 457 & 455 & 469 \\
\hline \multirow[t]{2}{*}{34.} & Tribanj & 513 & 481 & 338 & 267 \\
\hline & Općina Jasenice & & & & \\
\hline \multirow[t]{2}{*}{35.} & Rovanjska*** & - & - & - & 320 \\
\hline & Ukupno: & 10922 & 10874 & 9954 & 9372 \\
\hline
\end{tabular}

Izvor: Državni zavod za statistiku, Službeni glasnik Grada Senja br.8/2010.Wikipedija (obrada autor)

* Do teritorijalne reorganizacije Republike Hrvatske ova naselja su bila u sastavu naselja Senj, a kao samostalna naselja postoje od 2011.

** Područje do $700 \mathrm{~m}$ n.v..

*** Naselje Rovanjska je do 1998. bilo u sastavu naselja Jasenice, nakon čega je postalo zasebno naselje temeljem Zakona o područjima županija, općina i gradova u Republici Hrvatskoj (NN 8/98). 


\section{Prirodni resursi}

Prirodni resursi su, osim radno sposobnog stanovništva i povoljnih izvora financiranja, važan temelj društvenog i gospodarskog razvoja nekoga područja. Oni predstavljaju prirodni potencijal stanovništvu i gospodarstvu kao izvor hrane, ogrjeva i vode, utječu na mikroklimu nekoga prostora i omogućavanju razvoj gospodarskih djelatnosti. Do 2015. u Republici Hrvatskoj je bilo zaštićeno 417 područja u različitim kategorijama, odnosno $8,58 \%$ ukupne površine države ili 12,25 \% kopnenog dijela i $1,94 \%$ teritorijalnog mora.

Od ukupnoga državnog teritorija Hrvatske 4,56 \% su parkovi prirode. U gospodarskom smislu je, za Velebitsko primorje i podgorje, značajan Park prirode Velebit. To je najveće zaštićeno područje u Republici Hrvatskoj, površine $2200 \mathrm{~km}^{2}$, širine 10 - $30 \mathrm{~km}$, a duljine $145 \mathrm{~km}$ od prijevoja Vratnik na sjeverozapadu do kanjona Zrmanje na jugoistoku. Velebit povezuje gackoličku zavalu s Jadranskim morem, a zbog posebnog režima upravljanja predstavlja ograničenje za razvitak nekih gospodarskih djelatnosti ${ }^{1}$. To se odnosi na neka područja Grada Senja i Općine Starigrad, dok je cijela Općina Karlobag obuhvaćena Parkom prirode Velebit i uključena u ekološku mrežu Natura 2000. Zbog toga je potrebno razvijati gospodarske djelatnosti koje ne će značajnije ugrožavati obilježja ovog zaštićenog prostora ${ }^{2}$.

Drugi važan prirodni resurs je Velebitski kanal koji je morski prolaz između Velebita i niza otoka (Krk-Prvić-Goli-Rab-Pag-sjeveroistočna obala Ravnih kotara), dug je oko 144 km i dubine od 60 - 106 m, ali je nepogodan za plovidbu zbog čestih udara bure. Nalazi se uz strmu kamenitu obalu kopna uz Jadransku magistralu, bez većih urbanih aglomeracija i industrija, sa šljunčanim i pjeskovitim plažama i uvalama. Morsko dno je kamenito, s bogatom florom uz obalu i brojnim izvorima pitke vode. Iza kamenitog morskog dna nalazi se pjeskovito morsko dno koje mu daje posebnu vrijednost u pogledu očuvanja ribljeg fonda, životinjskih i biljnih organizama i čistog mora kao prirodnog bogatstva Republike Hrvatske.

\footnotetext{
${ }^{1}$ Planinski masiv Velebita 1978. godine uvršten je u mrežu međunarodnih rezervata biosfere UNESCO-a (NP Sjeverni Velebit, 2015.). U rezervatu biosfere primjenjuje se zonalno upravljanje područjem kojeg čini područje jezgre, prijelazno područje i zaštitna zona.

${ }^{2}$ U Zakonu o zaštiti okoliša (NN 80/13) navodi se kako je: "potrebno prirodna dobra i krajobrazne vrijednosti nastojati očuvati na razini obujma i kakvoće koji ne ugrožavaju zdravlje i život čovjeka i nisu štetni za biljni i životinjski svijet, te ih koristiti na održivi način tako da se ne umanjuje njihova vrijednost za buduće naraštaje."
} 


\section{Stanovništvo Velebitskog primorja i podgorja}

Kad je riječ o broju i strukturi stanovništva, Velebitsko primorje i podgorje je u prošlosti prolazilo kroz velike demografske promjene. Razlozi tomu su višestruki: loša ekonomska ili politička situacija, nepovoljni klimatski uvjeti za život, prometna izoliranost, gospodarski slaba gradska središta. Najveće su negativne demografske promjene nastale na području današnje Općine Karlobag, u kojoj se broj stanovnika smanjio za više od četiri puta (od 1910. do danas). Ovakvim trendovima pogodovale su, naročito nakon II. svj. rata: sporo provođenje industrijalizacije, urbanizacije i deagrarizacije, zbog čega je došlo do ubrzane emigracije i, naravno, depopulacije. Tijekom Domovinskog rata (1990. - 1995.) i srbijansko-crnogorske agresije na državu Hrvatsku, Velebitsko primorje i podgorje, osim južnog dijela, nije bilo izloženo ratnim operacijama, ali je važnu ulogu imalo u prometnomu povezivanju južne Hrvatske i dijela Bosne i Hercegovine s drugim dijelovima Republike Hrvatske i zbrinjavanju prognanika i izbjeglica. Unatoč tomu ipak je došlo do gospodarskog zaostajanja ovoga ruralnog područja i negativnih demografskih kretanja.

Demografsko stanje se nije značajnije promijenilo ni u novijoj povijesti jer na njega velik utjecaj ima stupanj društveno - gospodarske razvijenosti, a ona ovisi o starosnoj, dobnoj i obrazovnoj strukturi stanovništva, posebno radno aktivnog stanovništva koje je nositelj gospodarskih djelatnosti. Stalna depopulacija i negativan prirodni prirast stanovništva doveli su do izumiranja stanovnika u pojedinima naseljima. Neka su područja samo u posljednjem desetljeću izumrla, kao što je slučaj s mjestom Velika Brisnica na području Grada Senja. Nemogućnost zaposlenja uzrokovala je povećanje stope nezaposlenosti i stalno iseljavanje mlađih osoba u veće gradove, tako da se zbog emigriranja stanovništva u makroregionalne centre ili u inozemstvo, na Velebitskom primorju i podgorju nalazi uglavnom staračko stanovništvo. Negativna demografska kretanja i vrlo duboka starost stanovništva predstavlja veliki problem za zdravstveni sustav, mirovinski sustav i sustav socijalne skrbi, jer je ovakvoj strukturi stanovništva otežan pristup zdravstvenim, socijalnim ili drugim uslugama. Uslijed takvih negativnih demografskih kretanja dolazi do smanjenja kontingenta radno aktivnog stanovništva. To znači da je, kao posljedica gospodarske nerazvijenosti, smanjen natalitet, a povećano iseljavanje stanovništva u mlađoj i zrelijoj dobi. Ovo je posebno važno za planiranje razvoja pojedinih gospodarskih djelatnosti u Velebitskom primorju i podgorju, jer da bi se neka sredina gospodarski i društveno razvijala mora imati određenu koncentraciju stanovništva sposobnog za reprodukciju i dovoljan kontingent radno sposobnog stanovništva. 


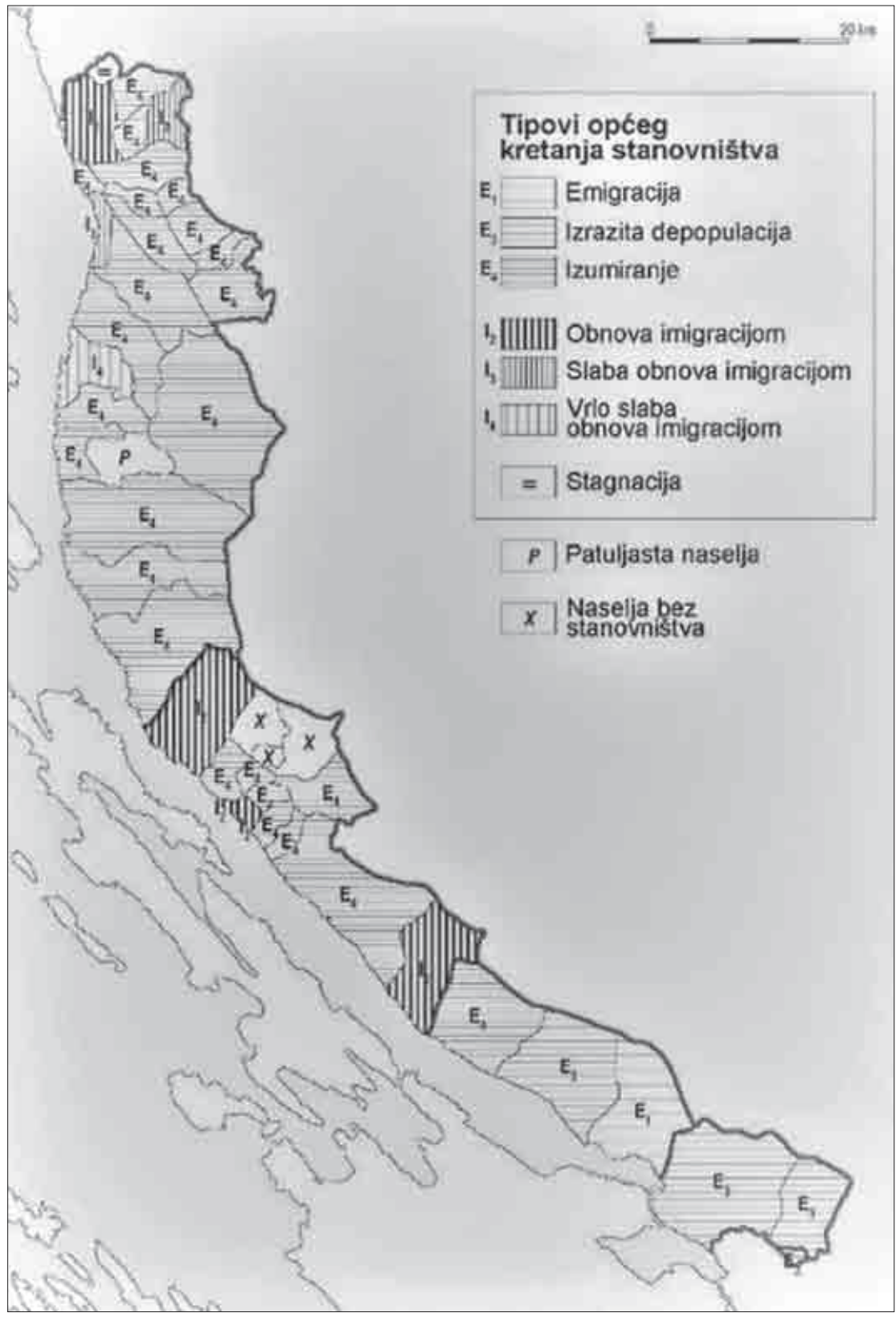

S1. 3. Opće kretanje stanovništva u naseljima Podvelebitskog primorja 1991.-2001., D. HUSANOVIĆ-PEJNOVIĆ, 2010. 
Negativna demografska kretanja Velebitskoga primorja i podgorja u prošlom stoljeću nastavljena su i u ovom stoljeću. Takva demografska kretanja su potaknuta globalizacijskim procesima pod čijim utjecajima je potražnja za radnom snagom. Ovi procesi utječu i na restrukturiranje gospodarstva, slobodno kretanje roba, ljudi i kapitala, velik uvoz roba i usluga pa je, naročito u tranzicijskim zemljama, smanjena domaća proizvodnja. Zbog svega navedenog došlo je do povećanja nezaposlenosti u Hrvatskoj, a visoka centralizacija države, slaba gospodarska snaga Velebitskog primorja i Podgorja, povećali su iseljavanje stanovništva u urbane sredine: Rijeku, Karlovac, Zadar, Šibenik ili Zagreb. Sve navedeno je dovelo do povećanja razlika između razvijenijih i nerazvijenih područja, nezainteresiranosti za investiranje u Velebitsko primorje i podgorje i u konačnici do usporavanja i gospodarskog propadanja cijelog područja.

$\mathrm{Na}$ slici br. 3. prikazani su tipovi demografskih resursa Velebitskoga primorja i podgorja iz koje je vidljivo da su demografski resursi slabi na području Senja, a izrazito slabi na području općina Karlobag, Starigrad i Jasenice.

\section{Dosadašnje djelatnosti u Velebitskom primorju i podgorju}

Nekada su glavne gospodarske djelatnosti Velebitskog primorja i podgorja bile poljoprivreda, ribarstvo i stočarstvo. Specifični zemljopisni i klimatski uvjeti usmjeravali su stanovništvo prema iskorištavanju pašnjaka u višim dijelovima Velebita (na Podima i Srednjoj planini) radi iskorištavanja pašnjaka i uzgoja poljoprivrednih kultura na manjima parcelama. Ratarska proizvodnja na primorskoj strani Velebita bila je zanemariva, rascjepkana na malene parcele po kamenjaru i šikarama. Sjetva i sadnja ratarskih kultura na malima parcelama je iziskivala puno ljudskog rada, a zbog malih prinosa i nekvalitetnoga tla nije podmirivala potrebe ni za osnovnim živežnim namirnicama koje bi bile dostatne kućanstvima. Tako A. Blanc (2003.,57) navodi: "hrvatski pedolozi (posebno Gračanin, koji je proučavao područje Senja) računaju da bi bilo potrebno na stotine tisuća godina da i u tipično sredozemnim klimatskim uvjetima nastane $35 \mathrm{~cm}$ debeo sloj zemlje koja potječe od dekalcifikacije vapnenaca." U takvim klimatskim i reljefnim uvjetima došlo je do razvoja stočarske proizvodnje i stvaranja tržišnih viškova, dok je poljoprivredna proizvodnja bila sporedna djelatnost. Stočarilo se na visinskima pašnjacima, gdje se moglo držati puno više sitne stoke nego je bilo potrebno domaćinstvu pa je prodaja tih viškova namirivala ostale potrebe u domaćinstvu. Za razvoj gospodarskih djelatnosti i 
razvoj stambenih naselja najvažnije je bilo područje od 0-500 m n.v., dok je područje iznad te visine (Srednja i Gornja planina), dakle područje od 700-1000 m n.v., povremeno korišteno za ispašu stoke i privremeno stanovanje. Kako navodi H. Knifić Shaps (2017.,1): "Potonje predstavlja cijelo područje života Podgoraca u stalnom hodu za vodom, od mora, do viših i visokih područja Velebita. Sredinom 19. stoljeća u Gajevoj Danici nepoznati je autor pisao da se Podgorci u proljeće "uz planinu do sriedine penju", da ljeti "poberu marvu, te se pod varhove Velebita na tretje stanove presele, gdie obilnu pašu i barst za marvu, a led po gudurah za rastapanje i napajanje marve nalaze". Do danas je ovakav način života gotovo potpuno nestao, osim manjih obiteljskih gospodarstava koja se pretežno bave uzgojem ovaca i koza.

Došloje do deagrarizacije koju nijenadomjestilaznatnija industrijalizacija Velebitskoga primorja i podgorja, osim Grada Senja i razvoja tercijarnih djelatnosti na području Grada Senja, općina Karlobag i Starigrad. Industrija je bila uglavnom radno intenzivna (drvna, tekstilna, metaloprerađivačka), stvorena nakon II. svj.rata procesom industrijalizacije. Slabo dohodovna industrija nije mogla zadržati radno aktivno stanovništvo i povećati naseljenost Velebitskog primorja i podgorja pa je došlo do velikog iseljavanja stanovništva. U novijoj povijesti ekonomski tranzicijski procesi i privatizacija doveli su do propasti industrije koja je postojala do Domovinskog rata. Razvoj drugih djelatnosti, kao npr. ribarstva bio je dosta otežan zbog klime i jakih vjetrova, iako su se u nekima primorskima mjestima stanovnici tradicionalno bavili ribarstvom. Turistička djelatnost Velebitskog primorja i podgorja također se slabije razvijala od ostalih primorskih ili dalmatinskih odredišta, znatnim dijelom isto zbog oštrije klime nego u drugima turističkima područjima ili strme obale, zbog koje je otežan pristup moru. Na slabi razvoj npr. turističke djelatnosti utjecao je i stav o turizmu kao djelatnosti u koju nije potrebno puno ulagati jer su more i sunce dovoljan razlog za boravak gostiju na nekomu odredištu. Osim toga razvoj turističke djelatnosti nije planski usmjeravan, povećanom broju posjetitelja prilagođavana je ponuda, a prednosti pojedinoga lokaliteta nisu se planski koristile.

Promet Velebitskog primorja i podgorja, kao izdužene zemljopisne cjeline određivao je, a i danas određuje, Velebit s jedne i morski kanal s druge strane. U dugom povijesnom razdoblju Senj je zbog luke bio važan prometni i tranzitni pravac, ali je izgubio na važnosti jer nije imao željezničku prugu ${ }^{3}$ koja bi ga povezivala s Gackom kao prirodnim zaleđem. Naravno da je tome

${ }^{3}$ Vidi: M. KOLAR, 1999, 247-284. 
pogodovala i izgradnja i razvoj luke Rijeka. Cijelim područjem Velebitskog primorja i podgorja prolazi nedovoljno protočna obalna prometnica "magistrala" (D8) koja je paralelna s plovnim Velebitskim kanalom. Ovaj prostor povezuje i nekoliko poprečnih cestovnih pravaca: od Senja preko prijevoja Vratnik prema Gackoj i Otočcu te od Karlobaga preko prijevoja Baške Oštarije prema Lici i Gospiću.

Pomorski promet ima dugogodišnju tradiciju. Najvažnije luke su bile, a i danas su Karlobag i Senj, a osim njih pomorski promet je određen lukama: Sv. Juraj, Donja Klada, Lukovo, Starigrad, Stinica - Mala Stinica, Prizna, Jablanac, Cesarica, Porat-Lukovo Šugarje, Barić Draga, te plovnim putovima Senj - Baška, Jablanac - otok Rab, Prizna Žigljen (Stara Novalja), Karlobag - Pag. Pomorski promet se odvijao, a odvija se i danas preko luka nautičkog turizma: Senj, Sv. Juraj, Lukovo, Starigrad, Stinica - Uvala Krivača, Karlobag, Lukovo Šugarje Uvala Porat. Ove luke su kategorizirane s obzirom na izgrađenu infrastrukturu i sigurnost te zaštitu priveza.

Iz ovoga kratkog prikaza vidljivo je da je razvojna politika bila usmjerena uglavnom na primarni sektor, a zbog nedovoljnoga tehničko tehnološkoga razvoja ostale djelatnosti nisu bile dovoljno snažne za pokretanje gospodarskoga razvoja. Ovo je svakako utjecalo na kontingent radno aktivnog stanovništva, ali i na razmještaj i obilježja domaćinstava Velebitskog primorja i podgorja tako da je apsolutni broj domaćinstava stagnirao, a broj članova domaćinstava se smanjivao.

\section{5. Čimbenici ograničenja gospodarskog razvoja}

Temeljni ograničitelj gospodarskog razvoja Velebitskog primorja i podgorja je mali broj i struktura stanovništva, posebno radno aktivnog stanovništva. Za formiranje i vođenje tvrtki koje bi se osnivale na ovomu području nedostaju, osim radne snage, i stručni kadrovi. Ovaj problem se rijetko ističe, a on je osim ideja, projekata i povoljnih izvora financiranja ključan činitelj gospodarskog razvoja.

Zbog zakonske regulative, a nakon proglašenja Parka prirode Velebit i nacionalnih parkova Sjeverni Velebit i Paklenica, došlo je do ograničenja razvoja niza gospodarskih djelatnosti na području Velebitskog primorja i podgorja, naime, zakonska regulativa uglavnom je usmjerena na zaštitu flore $\mathrm{i}$ faune te očuvanje prirodnog resursa. Kao vrlo vrijedan dio prirodnih resursa i prostor posebnih prirodnih vrijednosti pojedini dijelovi prirode su zaštićeni zakonom i upisani u Upisnik zaštićenih dijelova prirode. Također je 
pod određenim oblicima zaštite kulturna baština kao što su npr. stare urbane jezgre i drugi nepokretni spomenici kulture na području Grada Senja, Općine Karlobag i Općine Starigrad, ali i ruralna tradicijska baština koja je uglavnom prepuštena propadanju. To podrazumijeva da je potrebno razvoj ostalih djelatnosti prilagođavati očuvanju ovih resursa.

Gospodarski razvoj ograničava nedovoljni kadrovski i financijski kapacitet Grada Senja i općina Karlobag, Starigrad i Jasenice. Zbog visoko centraliziranoga državnog ustrojstva sposobnost jedinica lokalne samouprave ograničena je uglavnom na lokalne intervencije. Ovo je posebno došlo do izražaja nestankom ili značajnim smanjenjem upravljačkih funkcija u korist države ili sjedišta županija, pa ovakve jedinice lokalne samouprave nemaju potrebne organizacijske i tehničke mogućnosti za privlačenje stručnog kadra većih kompetencija i specijalističkih znanja. Marginalizirana je uloga općina i gradova koje su, kao jedinice lokalne samouprave, najbliže interesima svojih stanovnika. Zato je nužna u znatnoj mjeri decentralizacija fiskalnog sustava u korist najnižih jedinica lokalne uprave i samouprave, što bi financijski osnažilo lokalnu samoupravu i pomoglo razvoju i jačanju gospodarskih aktivnosti krajeva kao što je Velebitsko primorje i podgorje, jer fiskalna decentralizacija doprinosi gospodarskom rastu i razvoju. Ne treba zanemariti ni činjenicu da bi se u takvima sredinama povećala stručna radna snaga koja bi mogla razvojno djelovati i podizati konkurentnost sredine.

Zakonom je jedinicama lokalne samouprave ostavljeno pravo na uređenje prostora, uređenje naselja i stanovanja, urbanističko planiranje, socijalnu skrb, komunalnu djelatnost, šport i tehnička kultura te zaštita i uređenje okoliša, što znači da one mogu minimalno utjecati na razvoj gospodarskih djelatnosti jer im je prioritet ulaganje u komunalni standard i komunalnu infrastrukturu, odnosno programe koji su namijenjeni zadovoljavanju javnih potreba. Teritorijalnim ustrojem države nakon 1994. nisu u potpunosti uzete u obzir gospodarske, demografske, povijesne i druge specifičnosti pojedinih područja poput Velebitskog primorja i podgorja. To je dovelo do povećanja ovisnosti lokalne samouprave o središnjoj vlasti i njezinim dotacijama.

Daljnja ograničenja gospodarskog razvoja odnose se na ograničene ili nepovoljne uvjete financiranja poduzetničkih aktivnosti, nedostatak kvalificirane radne snage, nedovoljnu podršku postojećima poduzetnicima i poduzetnicima početnicima iz lokalne sredine. Gospodarstvo ovakve regije zasniva se na malima i srednjima poduzećima koje nemaju dovoljno jak financijski i kadrovski kapacitet, a da bi se na tržištu mogle ravnopravno nositi $\mathrm{s}$ velikim tvrtkama, potrebna je veća potpora regionalne i središnje vlasti. Mala 
i srednja poduzeća su često u nepovoljnijem položaju od velikih poduzeća kada je riječ o dostupnosti izvora financiranja, što im smanjuje konkurentnost na tržištu u odnosu na velika poduzeća. Zbog nedostatka financijskih sredstava ovakva poduzeća teže dolaze do nove opreme, nemaju sredstava za ulaganje u promidžbu, analizu tržišta ili konkurencije i sl. Ulaskom Hrvatske u Europsku uniju došlo je do porasta konkurencije na tržištu o čemu A. Kumar i V. Kandžija, (2015., 9.) ističu da: "porast konkurencije može ugroziti egzistenciju brojnih lokalnih poduzeća." Zato gospodarstvo na prostorima, kao što je Velebitsko primorje i podgorje nije moguće razvijati bez određenih oblika državnih potpora i povoljnoga makroekonomskog okruženja. Povoljno okruženje bi se prije svega odnosilo na povoljnu investicijsku klimu i podršku malima i srednjima poduzećima koja bi osnivali poduzetnici s prebivalištem na području Velebitskog primorja i podgorja.

Infrastruktura i komunalni sustav su također ograničitelji gospodarskog razvoja pa je važno voditi brigu o organizaciji sustava za odvodnju otpadnih voda, određivanje lokacija i uređenje sanitarnih deponija komunalnog otpada, osiguranje dovoljne količine vode za stanovništvo i gospodarstvo, kvalitetnu prometnu povezanost. Jedinice lokalne samouprave na području Velebitskog primorja i podgorja su svjesne ovih ograničenja i svojim su prostornima planovima predvidjele lokacije za ove infrastrukturne objekte. U prostornima planovima se o ovome vodi računa, jer je za lokalni i regionalni razvoj nužno postojanje i dobro funkcioniranje gospodarske, tehničke, tehnološke i ostale infrastrukture kao poticaj osnivanju i radu malih i srednjih poduzeća.

\section{Planirane gospodarske djelatnosti}

Glavne gospodarske djelatnosti Velebitskog primorja i podgorja jesu: trgovina, turizam i ugostiteljstvo, dok je proizvodnja zastupljena u manjem omjeru. Da bi se procijenilo koje gospodarske djelatnosti je moguće razvijati na ovome području analizirane su strategije razvoja i prostorni planovi jedinica lokalne uprave i samouprave.

Prema ovim dokumentima na području Grada Senja planirane su lokacije za vjetroparkove i solarne parkove te izgradnja luka za javni promet županijskog značaja: Senj, Prizna, Jablanac i Stinica - Mala Stinica, te luke za javni promet lokalnog značaja: Sv. Juraj, Donja Klada, Starigrad, Lukovo i Stinica - Krivača, luke nautičkog turizma: Senj, Lukovo, Starigrad, Sv. Juraj, Stinica - Krivača te športske i ribarske luke: Senj i Sv. Juraj. 
Tablica 2. Planirani kapaciteti i lokacije luka

\begin{tabular}{|c|c|c|}
\hline Položaj & Kapacitet & Napomena \\
\hline Senj & & neizgrađeno \\
\hline Senj & do 200 vezova u moru & neizgrađeno \\
\hline Stinica (uvala Krivača) & do 200 vezova u moru & neizgrađeno \\
\hline Lukovo & do 50 vezova u moru & neizgrađeno \\
\hline Starigrad & do 50 vezova u moru & neizgrađeno \\
\hline Sv. Juraj (uvala Jablanova) & do 200 vezova u moru & \\
\hline
\end{tabular}

Izvor: Županijska razvojna strategija Ličko-senjske županije 2011. - 2013., 30.

Za ugostiteljsko-turističku djelatnost i izgradnju etnosela i ekosela planirana su naselja koja su potpuno ili najvećim dijelom napuštena. Izgradnja takvih bi bila u naseljima: Jablanac (Gornji Bileni, Štokić Pod i Trolokve), Klada (Donji Zagon, Gornji Zagon, Gornja Klada - Dragičevići, Gornji Legci), Lukovo (Markovac, Panos, Trnovac), Prizna (Banovača, Borovački Pod, Jovanović Padež, Kurtuša, Marama, Prpić Lug, Starčević Pod), Starigrad (Devčići, Devčić Brig, Vučići), Stinica (Male Brisnice), Stolac (Krč), Sv. Juraj (Babić Dolac, Bilopolje, Gornja Smokvica, Skorupov Dolac, Šopinica, Vukelići), Velike Brisnice (Kirini, Jerkovići), Volarice (Devčići, Žuninac).

Također je ugostiteljsku i turističku djelatnost u Gradu Senju moguće razvijati i na lokacijama: Brduša (Podbilo), Markovinova Draga (Mrzli dol), Šojati (Veljun), Krčevina (Veljun), Vrtline (Veljun), Pod grebenom (Vrataruša), dok bi se ostale djelatnosti razvijale na području Vrataruše (Ošlje polje i Široki brig), a u Klaričevcu adrenalinski park. Za uzgoj riba i drugih morskih organizama određene su lokacije: Vela Ivanča, Trsine, Tvrduša, Vlaka, Burnjača, Bilančevica, Svatska, Boćarije Vele, Tvrduša (Prizna).

U Općini Karlobag prioritet je razvoj infrastrukture sve da se poveća održivost cijelog područja. Planirana je izgradnja riva i luka, obalne ceste, sustava vodoopskrbe i odvodnje, vjetroelektrana, solarnih parkova, plimnih turbina, stanica za prikupljanje, odvajanje i odvoz otpada. Proizvodne djelatnosti i ugostiteljsko-turističke djelatnosti bi bile na ukupno 33,52 ha, a odnosili bi se na manje proizvodne pogone, stočarske farme, skladišne prostore i servise. Ove djelatnosti bi se razvijale u dvjema izdvojenima poslovnim zonama unutar kojih bi se mogli graditi manji proizvodni pogoni ekološki prihvatljivi. Moguća je izgradnja i pojedinačnih građevina ugostiteljsko-turističke namjene za smještaj, kao što su hoteli, pansioni, prenoćišta (kapaciteta do 80 kreveta). 
Tablica 3. Kapaciteti i lokacije turističkih objekata Grada Senja

\begin{tabular}{|c|c|c|c|c|}
\hline Grad Senj & kamp & 2,0 ha & 180 korisnika & izgrađeno \\
\hline Bunica & kamp & $\begin{array}{c}0,3 \text { ha } \\
1,0 \text { ha }\end{array}$ & $\begin{array}{c}100 \text { korisnika } \\
100 \text { kreveta }\end{array}$ & $\begin{array}{c}\text { izgrađeno } \\
\text { neizgrađeno }\end{array}$ \\
\hline Spasovac & kamp & 0,33 ha & 100 korisnika & izgrađeno \\
\hline Ujča & hotel, turističko naselje & 4,80 ha & 500 kreveta & $\begin{array}{c}\text { djelomično } \\
\text { izgrađeno }\end{array}$ \\
\hline Kalić & hotel, turističko naselje & 6,2 ha & 380 kreveta & neizgrađeno \\
\hline Jablanova & hotel, kamp & 2,5 ha & 300 kreveta/korisnika & izgrađeno \\
\hline Rača & hotel, turističko naselje & 8,7 ha & 570 kreveta & $\begin{array}{c}\text { djelomično } \\
\text { izgrađeno }\end{array}$ \\
\hline Žrnovnica & 13,2 ha & 1000 kreveta & neizgrađeno \\
\hline Zidine & turističko naselje, kamp & 3,1 ha & 180 kreveta/korisnika & neizgrađeno \\
\hline Lukovo-Zala & hotel, turističko naselje & 3,8 ha & 230 kreveta & neizgrađeno \\
\hline Rastovača & hotel, turističko naselje & 10,0 ha & 800 kreveta & neizgrađeno \\
\hline Lomivrat, Javorina & & &
\end{tabular}

Izvor: Županijska razvojna strategija Ličko-senjske županije 2011. - 2013., 35-36.

Budući da na području Općine Karlobag nema luka za nautički turizam, planirano je izgraditi dvije luke za nautički turizam na moru s ukupno 400 vezova i dvije luke za nautički turizam na kopnu (suhe marine) sa 100 vezova. Poljoprivrednu proizvodnju nije moguće značajnije razvijati jer nema osobito vrijednih niti vrijednih tala (P1 i P2), dok su obradiva tla treće kategorije (P3) zastupljena na 167,5 ha ili oko $6 \%$ površine općine. Na tima površinama je moguća izgradnja staklenika ili plastenika, dok su za uzgoj ribe predviđene lokacije: uvale Koromačina, Smojveruša, Marasovića, Pečci, Kralić do uvale Drvarica, Badnjina i područje izvan uvale Porat.

Prema prostornima planovima ${ }^{4}$ uređenja Općine Starigrad turizam i tercijarne djelatnosti su glavne gospodarske grane koje treba razvijati, a one bi omogućile razvoj trgovine, servisa i drugih uslužnih djelatnosti. Predviđene

${ }^{4}$ Ovaj prostorni plan prilagođen je odredbama Uredbe o uređenju i zaštiti zaštićenog obalnog područja mora koja se temelji na izmjenama Zakona o prostornom uređenju (NN 100/04.) u odnosu na utvrđene kriterije o izgradnji i korištenju priobalnog pojasa mora. Plan je usuglašen s Prostornim planom uređenja Zadarske županije koji je regulirao kriterije izgradnje građevinskih područja naselja i drugih namjena u prostoru. 
Tablica 4. Kapaciteti i lokacije turističkih objekata Općine Karlobag

\begin{tabular}{|c|c|c|c|c|}
\hline Općina Karlobag & & & & \\
\hline Paški Porat & hotel, turističko naselje & 17,0 ha & 1700 kreveta & neizgrađeno \\
\hline Gaj & kamp & 4,0 ha & 400 korisnika & neizgrađeno \\
\hline Karlobag & kamp & 1,5 ha & 150 korisnika & neizgrađeno \\
\hline
\end{tabular}

Izvor: Županijska razvojna strategija Ličko-senjske županije 2011.-2013., 35-36.

su turističke zone koje bi bile u funkciji razvoja turizma, dok se u sastavu naselja predviđa formiranje mješovitih zona za obiteljski turizam zasnovan na maslinarstvu kao osnovnoj poljodjelskoj aktivnosti. Osim postojećeg kapaciteta od 1000 kreveta na 16 ha, planirana je izgradnja turističko-hotelskih kapaciteta sa 4300 kreveta na 68 ha. Osim ovih kapaciteta u Selinama, Marasovićima, Milovcu i uvali Pisak planirana je izgradnja nekoliko manjih kapaciteta od 100 - 300 kreveta na područjima Šibuljine i Tribanj.

Razvoj proizvodnih djelatnosti dosta je zanemaren pa su planirane manje proizvodne zone u okviru građevinskih područja, jer unutar zaštitna obalna pojasa nije moguća gradnja. ${ }^{5}$ Ove bi proizvodne zone bile u funkciji servisiranja osnovne djelatnosti, uređenih i prirodnih zona obale za različite namjene. Za uzgoj ribe i školjaka planiran je prostor u Velebitskom kanalu s minimalnim aktivnostima, s obzirom na ograničeni akvatorij.

Poljoprivredna proizvodnja ove općine je jedino moguća na malima površinama u području Velike i Male Paklenice. Na području Starigrada od 5687 ha za poljoprivrednu djelatnost može se iskorisitit 515 ha ili 9,05\%, na području Selina od 5104 ha može se iskoristiti 215 ha ili 4,21 \%, i na području Triblja od 6124 ha za poljoprivrednu proizvodnju iskoristivo je 210 ha ili 3,43 \%. Dakle, na području ove lokalne jedinice od 16915 ha za poljoprivrednu proizvodnju može se koristiti svega 940 ha ili 5,56 \%. Zbog nedostatka vode, jakog utjecaja bure i malenih te humusom oskudnih poljoprivrednih površina, voćarstvo, maslinarstvo, vinogradarstvo, vinarstvo i povrćarstvo se ne može značajnije razvijati, osim za osobne potrebe po kućnim vrtovima. Stočarstvo (uzgoj ovaca i koza) moguće je razvijati, pri čemu bi se sadašnje stado od 2000 grla moglo povećati na 10000 grla.

5 Nije dopušteno istraživanje i iskorištavanje mineralnih sirovina (osim morske soli), iskorištavanje snage vjetra, skladištenje, obrada i odlaganje otpada, privez izvan građevinskog područja, sidrenje itd. 
Prema Prostornom planu uređenja Općine Jasenice, naselje Rovanjska nalazi se u području od posebne državne skrbi. Velike su mogućnosti za razvoj ugostiteljsko-turističke djelatnosti budući se na području općine nalaze tri prirodne vrijednosti zaštićene zakonom ${ }^{6}$, i to: dio Parka prirode Velebit, geomorfološko-hidrološki rezervat Zrmanja i spomenik prirode Modrić pećina. U prostoru ovih špilja moguće je locirati ugostiteljske i trgovačke sadržaje površine do $150 \mathrm{~m}^{2}$ bruto, a planirano je izgraditi vučnu žičaru od naselja Rovanjska preko Kitnaste glavice prema Debelom brdu, što je za ovo naselje od izuzetnog značaja. Na slabo naseljenom prostoru Općine Jasenice nema puno obradiva zemljišta. Od 8639 ha obradive površine iznose samo 240 ha, od čega je na području naselja Rovanjska cca 90 ha, pri čemu je u građevinskom smislu moguće iskoristiti 68,13 ha. Do sada je od ove površine već izgrađeno 44,46 ha (uglavnom kuće za odmor). Izgradnja je dopuštena 70 m od mora, i to ugostiteljsko-turističkih kapaciteta do 70 postelja, a sadržaji iz trgovinske i uslužnih djelatnosti mogu se graditi do najviše $1500 \mathrm{~m}^{2}$ bruto izgrađene površine. Važnu razvojnu ulogu će imati turistička zona na području Rovanjske bruto površine 18 ha, u kojoj su planirane parcele za ugostiteljskoturističke, uslužne i športsko-rekreacijske namjene.

Danas se pomorski promet naselja Rovanjska bazira na prometu manjih plovila lokalnog stanovništva i izletničkih brodova koji plove akvatorijem Velebitskog kanala i Novigradskog mora, dok bi se u budućnosti pomorski promet razvijao kroz luku za nautički turizam koja za sada nema status luke za javni promet. Predviđeno je da luka može imati na jednom lokalitetu 10 vezova, a na drugom 200, dakle ukupno 210 vezova, pri čemu u lučici do 10 vezova nije moguća izgradnja pratećih sadržaja. Prostornim planom je predviđena izgradnja i uređenje privezišta i istezališta s površinama za popravak i održavanje brodica te drugih pratećih sadržaja.

\section{Mogući instrumenti razvoja gospodarstva Velebitskog primorja $i$ podgorja}

Zbog već navedenih ograničenja teško je očekivati zainteresiranost investitora za ulaganje $\mathrm{u}$ industriju, ali bi se mogla značajnije razvijati ugostiteljsko-turistička djelatnost stimuliranjem razvoja specifičnih oblika turizma u višim dijelovima Velebita, tim više što je priobalno područje turistički razvijenije od gacko-ličkog i vršnog područja, što je prilika da se

\footnotetext{
${ }^{6}$ Zakon o zaštiti prirode, NN br. 162/03.
} 
turistički značajnije afirmira vršno područje Velebita jer ono može svoju privlačnost zasnivati upravo na prirodnim ljepotama ovoga planinskog masiva. Osim održivog razvoja prostora poželjno bi bilo disperzirati gospodarske jedinice na području Velebitskog primorja i podgorja uz korištenje tradicijskih i autohtonih načina korištenja prostora. Posebno značajnu ulogu u razvoju gospodarstva mogu imati Park prirode Velebit i nacionalni parkovi Sjeverni Velebit i Paklenica. Prilikom razvoja turističke djelatnosti, ponudu i kapacitete treba razvijati tako da se oni povezuju s turističkim kapacitetima i ponudom gacko-ličkog zaleđa.

Sjedišta jedinica lokalne samouprave moraju postati razvojna žarišta, pri čemu bi bilo poželjno odrediti još neka naselja kao razvojne točke i pomagati ih raznima državnima poticajnima mjerama. Veliku ulogu u poticanju održivoga razvoja bi mogle imati lokalne akcijske grupe (LAG) ${ }^{7}$. Osnivanjem LAG-a, "Velebitsko primorje i podgorje" koje bi obuhvatilo Grad Senj i općine Karlobag, Starigrad i Jasenice stvorila bi se dobra poveznica primorskoga i gacko-ličkoga prostora, te okupilo postojeće ljudske i financijske resurse.

Fiskalna i teritorijalna decentralizacija je mjera koja bi omogućila snažnije kadrovsko ekipiranje u jedinicama lokalne samouprave i bolje iskorištenje različitih izvora financiranja, kao što su sredstva EU. Ulaskom Republike Hrvatske u EU otvorena je mogućnost korištenja sredstava iz Europskog poljoprivrednog fonda za ruralni $\mathrm{razvoj}^{8}$, Europskog fonda za regionalni razvoj, Kohezijskog fonda i Europskog socijalnog fonda čiji je cilj smanjenje socijalnih, ekonomskih i teritorijalnih razlika, otvaranje radnih mjesta, održivi razvoj i ravnomjerno razvijanje gospodarstva svih država i članica EU.

Također bi trebalo izraditi plan gospodarskog i društvenog razvoja Velebitskog primorja i podgorja jer su sada razvojne aktivnosti raspršene u planovima i strategijama županija, gradova i općina. Zato bi kvalitetan razvojni pomak ovoga prostora bio formiranje tijela koje bi okupilo stručnjake različitih disciplina, a koje bi imalo savjetodavnu ulogu i kroz angažiranje na raznima projektima ili "lobiranje" u pojedinim institucijama. To bi omogućilo jače artikuliranje gospodarskih i demografskih problema prema državnim institucijama, koje nisu do sada selektivnom politikom i poticajnim mjerama utjecale na zaustavljanje migracije stanovništva, povećanje radno aktivnog

${ }^{7}$ Lokalne akcijske grupe (LAG) su oblik lokalnih javno-privatnih partnerstava iz različitih socioekonomskih okruženja.

${ }^{8}$ Uredba Vijeća ministara o financiranju CAP-a od 21.6.2005.(OJ L 209,11.8.2005.). 
kontingenta i omogućile razvoj gospodarstva. Razvojem gospodarstva, otvaranjem radnih mjesta i privlačenjem radne snage u Velebitsko primorje i podgorje ostvario bi se glavni cilj, tj. da se zaustavi demografska devastacija prostora i poveća naseljenost ovoga prostora.

\section{Zaključak}

Velebitsko primorje i podgorje je područje značajnih prirodnih resursa od kojih su, u gospodarskom smislu, najvažniji Park prirode Velebit i Velebitski kanal. Park prirode Velebit je najveće zaštićeno područje u Republici Hrvatskoj koje povezuje Jadransko more s gacko - ličkom zavalom, a zbog posebnog režima upravljanja ograničenje je razvoju nekih djelatnosti. Velebitski kanal je morski prolaz između Velebita i niza otoka dužine oko $144 \mathrm{~km}$ i dubine od 60 do $106 \mathrm{~m}$ sa strmom i kamenitom obalom uz Jadransku magistralu. Važan je u pogledu pomorskog prometa i očuvanja čistog mora i životinjskih i biljnih organizama.

Ovo ruralno područje, gospodarski i demografski je devastirano, a na njemu obitava uglavnom staračko stanovništvo i malen kontingent radno aktivnog stanovništva. Nekada su glavne gospodarske djelatnosti bile poljoprivreda, ribarstvo i stočarstvo koje je zamijenila radno intenzivna i slabo dohodovna industrija. Nemogućnost zaposlenja dovela je do stalnog iseljavanja mlađih osoba u veće gradove ili u inozemstvo, pa i do izumiranja stanovnika u pojedinim naseljima Velebitskog primorja i podgorja. Nužnost gospodarske revitalizacije ovoga prostora prepoznale su jedinice lokalne samouprave, i svojima prostornima planovima i drugima razvojnim dokumentima odredile lokacije i djelatnosti koje namjeravaju razvijati. Planiraju razvijati prometne i uslužne djelatnosti, ugostiteljstvo i turizam, građevinarstvo te komunalnu djelatnost.

Za gospodarski razvitak nužno je zaustaviti demografski pad, jačati kadrovski potencijal na lokalnoj razini i raznim mjerama poticati poduzetništvo, te bolje koristiti prirodne resurse. Ovo bi omogućila teritorijalna i fiskalna decentralizacija države, pojednostavljenje uvjeta dobivanja sredstava iz EU fondova i disprerzija gospodarskih djelatnosti na području Velebitskog primorja i podgorja. 


\section{Literatura}

André BLANC, Zapadna Hrvatska, Zagreb, 2003.

Grad Senj, Strategija razvoja Grada Senja 2015.-2020., Sense savjetovanje d.o.o., Senj, 2015.

Grupa autora, Županijska razvojna strategija Ličko-senjske županije 2011.-2013.

Grupa autora, Lokalni sustavi malih poduzeća, Ekonomski fakultet Split, Split 2000.

Dragica HUSANOVIĆ-PEJNOVIĆ, Demografski razvoj Podvelebitskog primorja u uvjetima periferije, Senjski zbornik, 37, Senj, 2010,119-142.

Industrijska strategija Republike Hrvatske 2014. - 2020., RH, Ministarstvo gospodarstva, Zagreb, 2014.

Vinko KANDŽIJA, Razvoj gospodarske konkurentnosti Republike Hrvatske kao članice EU, Ekonomski fakultet Sveučilišta u Rijeci, Rijeka, 2015, 9.

Vinko KANDŽIJA - Igor CVEČIĆ, Ekonomika i politika Europske unije, Ekonomski fakultet Sveučilišta u Rijeci, Rijeka, 2010.

Helena KNIFIĆ SCHAPS, Podgorska pučka gradnja kao evolucijska sinteza emotivne i materijalne kompozicijske komponente, (rad u pripremi), Senjski zbornik, 44, Senj, 2017.

Helena KNIFIĆ SCHAPS, Velebit arhitektonski, Pučka gradnja u dijelovima Sjevernog i Srednjeg Velebita, Zagreb, 2013, 25.

Mira KOLAR, Senjska željeznica, Senjski zbornik, 26, Senj, 1999, 247-284.

Ličko-senjska županija: Prostorni plan Ličko-senjske županije, Gospić, 2002.

Odluka o donošenju Prostornog plana uređenja Općine Karlobag, Županijski glasnik Ličko-senjske županije, 3/04. od 2008.

Općina Jasenice, Prostorni plan uređenja Općine Jasenice, Aces d.o.o. Zadar, 2005.

Prostorni plan uređenja Općine Starigrad, Block-Projekt d.o.o., Zadar, 2011.

Veljko ROGIĆ, Razlike pejzaža velebitskih padina, Geografski glasnik, 18, Zagreb, 1956, 15.

Strategija razvoja Općine Karlobag 2015.-2020.

Zakon o zaštiti okoliša, Narodne novine, 80, Zagreb, 2013.

Dražen ŽIVIĆ - Ivo TURK - Nenad POKOS, Regionalni aspekti depopulacije Hrvatske (1991.-2011.), Mostariensia, 18, Mostar, 1-2, 2014, 231-251. 


\section{CURRENT AND POTENTIAL ACTIVITIES IN THE VELEBIT PRIMORJE AND PODGORJE (LITTORAL AND FOOTHILL) REGIONS}

\section{Summary}

The economic and demographic picture of the Velebit Primorje (littoral region) and Podgorje (foothill region) is not good due to the following causes: the unattractiveness of the relief of the place from an economic point of view, the high degree of environmental protection, which for an entrepreneur is an additional expense, the unfavourable conditions of financing entrepreneurship as well as the high degree of state centralisation. The basic cause of this kind of overall economic situation is the small number and structure of the population, in other words, the insufficient, actively working contingent of the population. The existing old age and educational structure of the population are unfavourable and insufficient for the development of the economy because of the demographic changes in the past, the conflicts of industrialisation, urbanisation and deagrarisation which resulted with emigration and depopulation. The once dominant activities of agriculture, fishing and livestock breeding, were replaced with tourism, trade and hospitality, and less production. For the economic development of this area the Velebit Nature Park and the Northern Velebit and Paklenica national parks are important as natural resources can influence the development of eco-production, eco-tourism and sustainable development.

Keywords: Velebit Primorje and Podgorje (littoral and foothill regions), actively working population, decentralisation, natural and human potential, economic development 